Vol. 2 No. 1- April 2021

\title{
Land Value Capture as Financial Resource for Infrastructure Development in Palembang City
}

\author{
Mabrurotunnisa ${ }^{1 *}$, Doddy Aditya Iskandar² \\ ${ }^{1}$ Regional Development Planning Board, Research and Development of Lubuklinggau, \\ Lubuklinggau, Indonesia \\ ${ }^{2}$ Gadjah Mada University, Yogyakarta, Indonesia \\ Email:1'mabrurotunnisa89@gmail.com, ${ }^{2}$ doddy@ugm.ac.id. \\ *) Corresponding author
}

\begin{abstract}
Indonesian local governments still depend on the state budget to fund infrastructure development. On the other hand, land value capture (LVC) is suitable for developing countries, such as Indonesia, to fund such development. However, there is an absent legal system to explicitly implement LVC in Indonesia. This paper aims to discuss factors affecting LVC implementation in the context of Palembang. Through an in-depth interview with several experts, the study identified existing issues affecting LVC implementation including delays in revising regulation; risk of corruption, collusion, and nepotism; decrease in public participation; and public complaints due to property tax increase. Finally, we proposed strategies that should be fulfilled by the local government for the successful implementation of LVC in Palembang. They include the establishment of an implementing agency with a clear division of role and skillful members, the enactment of specific regulations, and the establishment of a special forum, eplatform, and mass media.
\end{abstract}

Keywords: land value capture, infrastructure, financing, land use, Palembang

ARTICLE INFO
Received: November 15, 2020
Received in revised form: March 12, 2021
Accepted: April 26, 2021

doi: 10.46456/jisdep.v2i1.96 (C) 2021 The Author
JISDeP - The Journal of Indonesia Sustainable Development Planning Published by Centre for Planners' Development, Education, and Training (Pusbindiklatren), Ministry of National Development Planning/ National Development Planning Agency (Bappenas), Republic of Indonesia
Address: Jalan Proklamasi 70,

Central Jakarta, Indonesia 10320

Phone: +62 21 31928280/31928285

Fax: +62 2131928281

E-mail:

journal.pusbindiklatren@bappenas.go.id

Supported by Indonesian Development Planners Association (PPPI) 


\section{Introduction}

The local governments are severely facing fiscal constraints, such as weak bond markets and heavy debt, that restrict them from funding infrastructure development (Mathur, 2015, 2019; White \& Wahba, 2019) and depend on the state budget to fund such development. Thus, they need to seek alternative sources to fund infrastructure development (Li \& Love, 2020; Mathur, 2014, 2019; Mittal, 2014). The local government uses Land Value Capture (LVC) as an alternative financial scheme for urban rail transit projects (Luan et al., 2014; Sharma \& Newman, 2018). LVC is also suitable for developing countries that still face financial constraints (Suzuki et al., 2015), decreasing demand for debt and debt service risk (Peterson, 2009). Governments in other countries, such as Japan (Suzuki et al., 2015), the United States (Zhao et al., 2010), and Hong Kong (Yau, 2012), already fund large projects through LVC mechanisms. In contrast, the Indonesian local government still depends on the state budget instead of an LVC scheme. For example, in the development of light rail transit (LRT) in Palembang, South Sumatera, the state government spent IDR 12.5 trillion for its construction (Komite Percepatan Penyediaan Infrastruktur Prioritas - Committee for the Acceleration of Priority Infrastructure Provision, n.d.).

The debate on how to optimize public service provisions, such as financing mechanisms, identification of alternative financing sources, and the involvement of the private sector in the provisioning process, cannot be separated from the emergence of rational choice or public choice theory. The public choice theory posits that the interaction between the local government and the community is akin to the interaction between producer and consumer (Buchanan, 1969; Buchanan \& Tullock, 1962; Ostrom \& Ostrom, 2004; Tiebout, 1956). Local government is perceived to be able to produce a bundle of public services, and this bundle of services is then offered to the consumer willing to purchase such services (Eisinger, 1988; Ostrom \& Ostrom, 2004). Community members appraise and value the quantity and quality of public services provided by the local government according to their preferences and willingness to pay. Community member purchases the whole or part of the bundle of services through their willingness to pay taxes (especially property taxes).

This idea culminates in the form of entrepreneurial government, in which government behaves and acts similar to the private sector (Osborne \& Gaebler, 1992). This does not mean that government focuses its activities on creating profit-making; instead, the government utilizes principles such as value for money and public sector comparator to produce effective and efficient public services (Eisinger, 1988; Weiss, 2014). This paradigm shift affects the way government approaches its strategy, including its view of creating infrastructure, which is considered a capital-intensive project. Instead of providing infrastructure through a sunk-cost perspective, the government is encouraged to also capture the financial and economic benefits accrued from the development of infrastructure. Governments as citizens' partners develop more innovative financing methods to provide more effective and efficient public services (Osborne \& Gaebler, 1992). In financing urban infrastructure, such innovation will improve the government's financial ability to fund infrastructure development (Kim, 2016; Medda, 2012). Governments are urged to be more self-resilient and cooperate with the private sector (Kim, 2016).

On the other hand, land value around some stations increased significantly during the development of LRT in Palembang (from 2015 to 2018). For instance, the land value zone (Zona Nilai Tanah - ZNT) around Bumi Sriwijaya Station experienced an average increase of 147 percent from 2015 to 2017 (The Palembang National Land Agency (Cartographer), 2015, 2017). The idea of value capture is based on the principle of beneficiary charges in transportation finance (Abelson, 2018; Suzuki et al., 2015) that highlight the importance of public-private partnerships (Medda, 2012). They believed that governments should involve a group of beneficiaries such as landowners and developers. LVC as an alternative financing scheme by Sustainable Development Goals (SDGs) Target 17.16 and 17.17 promote multi-stakeholder partnerships to achieve SDGs Target 9.1. and 11.2, which encourage quality public infrastructure and expand public transport.

By considering the concept of value capture, where the government can capture land value increment around transit nodes (Mathur, 2019; Smolka, 2013; Suzuki et al., 2015) caused by transport investments (Mathur, 2014), the municipal government can fund infrastructure development in Palembang through LVC scheme. Even though LVC instruments, such as tax, planning gain, betterment levy, and development impact fee, have been implemented in Indonesia, it has not fully fulfilled the value capture principles (Wisnu, 2019). Moreover, an absence in the legal system prevents the local government from explicitly implementing LVC in Indonesia. 
Studies about LVC can be discussed quantitatively or qualitatively. In quantitative research, researchers generally evaluated the LVC implementation throughout the world, such as London (Roukoni \& Medda, 2012), China (Wu et al., 2018), and Hong Kong (Loo et al., 2018). Some went on to calculate and forecasting value that governments could capture from land value increment (Berawi et al., 2019; Falcocchio et al., 2018; Higgins, 2019; Sharma, 2018; Sharma \& Newman, 2018; Xu et al., 2019). Qualitative research primarily evaluated the LVC implementation through document reviews (Budiati, 2020; Mathur, 2014, 2015, 2017, 2019; Yilmaz et al., 2015) and specifically, based on the general principle of public finance (Abelson, 2018; Gielen \& Mualam, 2019; Roukoni \& Medda, 2012; Zhao et al., 2010; Zhao \& Larson, 2011). Other research identified the opportunities for LVC implementation through a comprehensive review of the literature (Salon \& Shewmake, 2011) and by comparing case studies (Neville, 2016). Nevertheless, very few researchers conducted LVC through in-depth interviews and focused group discussion (Gunawan \& Berawi, 2018; Yau, 2012) because they are more time-consuming and challenging to draw a consensus. Moreover, few studies discuss the opportunity for LVC implementation in Indonesia (Gunawan \& Berawi, 2018; Wisnu, 2019).

Numerous studies have explored LVC implementation worldwide. The following studies provide an understanding of preconditions for the success of LVC implementation: institutional and regulatory readiness and public acceptance. In implementing LVC tax-based instruments, it is necessary to establish supportive regulation (Zhao \& Larson, 2011) such as a clear mechanism in a jurisdiction (Kerth \& Baxandall, 2011; Zhao et al., 2010) and strong government institutions at the state-level and city-level (Mathur, 2014). Moreover, tax-based instruments require a robust real estate market, updated and accurate cadastral data, strong coordination among stakeholders, and support from property owners (Abelson, 2018; Mathur, 2014, 2017; Mathur \& Smith, 2012; Zhao \& Larson, 2011).

In the same way, studies found that in implementing LVC development-based instruments, it is important to have adequate institutional and regulatory support (Gielen \& Mualam, 2019; Mathur, 2015; Mittal, 2014; Suzuki et al., 2015; Zhao et al., 2010). Government officials should have high technical knowledge and management skills (Aveline-Dubach \& Blandeau, 2019). The local government also needs to establish effective and efficient land development control such as cadastral data (Gielen \& Mualam, 2019) and provide a stronger incentive mechanism (Suzuki et al., 2015) by creating well-functioning financial institutions (Kim, 2018). Some scholars also highlight the importance of achieving stakeholders consensus and coordination (Zhao et al., 2010) by conducting public forums (Yau, 2012), creating a transparent project scheme (Yilmaz et al., 2015), and a clear division of stakeholders' roles (Yilmaz et al., 2015), and providing knowledge to landowners and developers (Suzuki et al., 2015; Yau, 2012). Furthermore, a significant land value increase and a robust real estate market (Aveline-Dubach \& Blandeau, 2019; Gielen \& Mualam, 2019; Kim, 2018; Mathur, 2015; Mittal, 2014) are also essential for the successful implementation of development-based instruments.

In this paper, we discussed factors affecting LVC implementation in the context of Palembang. The study used an in-depth interview with possible experts for LVC implementation in Palembang. Finally, we propose strategies to strengthen the enabling factors as a material consideration for the local government to implement LVC in Palembang.

\section{Methodology}

This paper involves a qualitative approach to discover the opinions and thoughts of the participants. This paper used in-depth interviews to understand the rationale of LVC implementation, which is difficult to capture through a quantitative study. As a sampling method, we used purposive sampling to explain research questions in information-rich cases (Creswell, 2009; Patton, 2002). We interviewed seven experts who are knowledgeable about land regulation, property taxation, and public-private partnerships in Palembang and understand LVC instruments.

Before the interview, we conducted a systematic review of several types of research to find the determinant factors of the success of LVC implementation throughout the world. The eligibility criteria of the references include topic, type of publication, year of study, language, academic field, and context (Permana \& Harsanto, 2020). This paper utilized two keywords: "infrastructure financing" and "land value capture" in the search engine because value capture is a form of infrastructure financing innovation. We limited the type of publication to English publications that consist of peer-reviewed articles, proceedings, government reports, books, and working papers. We then sorted the articles by the academic fields related to land use, transportation, and urban planning. We downloaded, read, and analyzed the publication published in the last ten years to obtain more relevant conditions about LVC implementation. 
We compared the publications by countries and LVC instruments. As a review framework, we grouped the findings into three thematic analyses: institutional, actors' support, and prerequisites.

Based on the systematic review of other countries' experiences with LVC, we concluded that key factors in LVC implementation consist of a strong institution, regulation, stakeholder consensus, and real estate market. Therefore, we focused the interview on two major topics: institutional and regulatory readiness and public acceptance. The objective of the interview is to obtain information from participants about enabling factors and hindrances that potentially affect the implementation of LVC instruments in Palembang. Thus, we developed the interview guideline that listed questions related to regulation, government institutional structure, public-private partnership, LRT development, and LVC implementation.

We considered that the background characteristics of the participants might influence the results. Thus we divided the participants into two groups: 1) Local government officials group that consists of representatives from Regional Development Planning Board Research and Development or (Bappeda Litbang), the Public Works and Spatial Planning Agency or (DPUPR), and the Regional Tax Management Agency (BPPD); and 2) Private sector and civil society group that consists of members of Association of Indonesian Housing and Settlement Developers (APERSI), a residential property owner, and a commercial property owner.

We conducted all interviews by voice call through a multiplatform messenger such as WhatsApp after we delivered a brief overview of LVC instruments to the participants through the same multiplatform messenger. We recorded, transcribed, and translated the interviews with participants' permission. Based on the interview transcription, we highlighted significant statements and quotes (Creswell \& Poth, 2018) that reveal how the participants act towards the phenomenon discussed in this paper. We cross-checked the information from the interview with government policies and documents to interpret the results. Thereby, we discovered more findings that are not stated in previous studies or previously conducted interviews. We later transformed those findings into several themes and delivered them into structural descriptions that show the essence of the phenomenon that was being studied (Creswell \& Poth, 2018). Finally, this paper proposes several solutions to deal with existing barriers and strengthen the existing enablers for successful LVC implementation in Palembang.

\section{Result and Discussion}

The following discussions revealed four main existing features that may strengthen LVC implementation, including the existence of regulations related to land use, property tax, public-private partnerships, clear division of authority in governance structure, effective coordination among stakeholders, and robust real estate market. We discovered several issues arising in the four key factors, including delays in revising regulation, risk of corruption, collusion, nepotism, decreased public participation, and public complaints due to property tax increase.

Most informants admitted that to succeed in LVC implementation in Palembang, the local government must guarantee that the existing local regulations (land use, property taxation, and publicprivate partnership regulations) are sufficient. One of their statements illustrated this point. A former secretary of a planning agency stated, "for land use, we [Palembang municipal government] has 20122032 regional spatial planning (RTRW), which is currently in the process of revision." However, she unwittingly revealed the surprising current situation of RTRW: the revising process of the regulation is delayed.

Even though she believed that "there are no obstacles [in the implementation of RTRW] because every stakeholder is already in agreement regarding the zones that have been regulated," the outdated regulation might affect LVC implementation in the future. In relation to this, a government official of a spatial planning agency argued that "spatial planning is dynamic, [therefore] spatial planning regulation has to be revised every five years." These findings aligned with Law No. 26/2007 about spatial planning that obligates each region to conduct a judicial review regarding RTRW. These findings also support previous research that acknowledged the essence of effective and efficient land development control in LVC implementation (Gielen \& Mualam, 2019; Zhao \& Larson, 2011).

The researcher also believes that supporting regulations in LVC implementation is not only about their existence but also their clarity in the jurisdiction (Kerth \& Baxandall, 2011; Zhao et al., 2010). This clarity might influence stakeholders' behaviors towards government actions. Following this argument, a government official, for example, described, "even though there were complaints from the public 
regarding the length of time for the permit [building permit] process, it has been resolved through the implementation of standard operating procedure (SOP) of the permits." This SOP shows that the process of applying for a building permit (Izin Mendirikan Bangunan - IMB) can be finalized in less than four hours. However, there might be a delay, revision, or refusal from the authorized officer during the permit process.

At the same time, the authorizing process still involves face-to-face interaction between government officials and citizens that may increase the risk of corruption, collusion, and nepotism (KKN) during the process. Budiati (2020) believed that the practice of bribery might occur between private contractors and public officers; as a consequence, the competition among bidders (i.e., contractors) would be unfair. This issue could be resolved using the online application. A government official from the public works agency believed that "through the Electronic Goods and Services Procurement (LPSE) system, the private sector does not need to come face to face with the government but through the website where they can avoid KKN." However, there is still uncertainty of clean governance because there is still a chance for both parties (the private sector and the government officials) to communicate outside the LPSE procedure.

The former secretary of the planning agency also believed that "clear division of authority among institutional structures of Palembang municipal government" is the key factor for successfully implementing several regulations, such as land use, property tax, and public-private partnership, in Palembang. The authority of the institutional structure of each agency in Palembang municipal government is regulated under major regulations about the positions, organizational structures, duties and functions, and work procedures of each agency. However, this changes many times due to changes in nomenclature, causing a transition in an agency's authority and function, as illustrated by the following statement of a government official:

RTRW was planned by Bappeda [Regional Development Planning, Research, and Development Agency or Bappeda Litbang] because it is related to spatial planning. Bappeda was intensively communicating with people who want to get information related to the function of space. But now, the authority is transferred to DPUPR. However, Bappeda is still the coordinator; for example, during the revision of RTRW, Bappeda is still involved in the process at the regional level, provincial level, and national level.

The authority of spatial planning was transferred from Bappeda Litbang to DPUPR based on Mayor Regulation Number 50/2016 about the Position, Organizational Structure, Duties, and Functions, and DPUPR's Work Procedures. This circumstance urged DPUPR, as a new responsible agency, to ensure that they can carry out these new tasks through adequate financial resources and skillful government officials. A possible interpretation arises that such kind of government structure reform hindered the process of RTRW revision. This finding is in line with those findings by Aveline-Dubach \& Blandeau (2019), who highlighted the urgency of having high technical government officials.

Most participants also acknowledged the critical role of dissemination to achieve stakeholders' consensus. A government official from the tax agency revealed that by "conducting dissemination to the public up to the lowest economic level about how important the role of the community is in regional development in particular," government could increase taxpayer awareness. Dissemination through various public forums and meetings can captivate stakeholders to participate in the development process through which they will obtain detailed information about government programs. The implementation of tax object sales value (NJOP), for example, involves a long dissemination process to respond to public complaints regarding NJOP adjustment through Mayor Regulation No. 51/2019 about Land and Building Tax Stimulant, which was introduced in July 2019.

Another respondent supported this statement. The former secretary of the planning agency illustrated several coordination schemes that accommodate cooperation among the government, the private sector, and civil society.

The official mechanism [to attract the participation of the private sector and civil society] is Musrenbang [the development planning forum]. In these forums, the municipal government invites the private sector through CSR [Cooperate Social Responsibility] forum. The private sector can get information about government programs before making decisions about which programs they are willing to help. Also, DPMPTSP [the Capital Investment and One-Stop Integrated Services Agency] actively conduct roadshow from event to event to offer cooperation in Palembang.

Musrenbang may be the biggest public forum at the municipal level through which stakeholders convey their aspirations, expecting realization in the next financial year. The literature also supports these findings. Yau (2012) suggests that public forums are important to achieve stakeholder consensus and create strong coordination. Unfortunately, data shows that the government cannot achieve the public 
proposal's target in 2019 (Public Works and Spatial Planning Agency, 2019). This may indicate that there is a weakness in the government's financial ability, so the government needs to prioritize the urgent and impactful public proposal. It may affect public awareness and decrease public participation in the development process.

Another important finding is that there is a potentially strong real estate market. This finding is in line with the arguments made by Mittal (2014), Mathur (2015), Kim (2018), Aveline-Dubach \& Blandeau (2019), and Gielen \& Mualam (2019). They suggest that significant land value increases and a robust real estate market are essential for the success of LVC implementation. A strong real estate market indicates a strong supply and demand for property. A member of developer associations, for instance, disclosed that "business [property business life] experienced an improvement due to an increase in selling prices of land and property." He interpreted that his company benefits from such increment even though the increase in property selling prices is probably is caused by the increase in property tax due to the NJOP adjustment in 2019. This interpretation would be consistent with government documents that found an increasing number of housing demands from citizens. See Government Agency Work Report (Laporan Kerja Instansi Pemerintah - LKjIP) of DPUPR (2019). From the government's point of view, this may be an opportunity to increase local tax revenue. On the other hand, developers may experience decline in the number of property sales because of public complaints related to property tax increases.

Even though a government official of spatial planning suggested that public complaints arise because "some people still lack understanding about zones regulation for determining property tax" and that "it is now solved because of the intense dissemination," the Regional Tax Management Agency (BPPD) revealed that they could not achieve their target of land and building tax (PBB) revenue in 2019 because some citizens objected to the new tax rate which was calculated using the NJOP adjustment (See Government Agency Work Report (LKJIP) of BPPD, 2019).

By linking findings from the previous discussion, this paper provides an overview of the enabling factors and barriers of LVC implementation in Palembang, as shown in Table 1.

Table 1: Strategies and Actions for LVC Implementation in Palembang

\begin{tabular}{|c|c|c|c|c|}
\hline Enabling Factors & Problems & Root Problems & Objectives & Actions \\
\hline $\begin{array}{l}\text { Existing local } \\
\text { regulation }\end{array}$ & $\begin{array}{l}\text { Delay in revising } \\
\text { regulation that causes } \\
\text { outdated data and } \\
\text { regulations }\end{array}$ & $\begin{array}{l}\text { Change in agency } \\
\text { authority }\end{array}$ & $\begin{array}{l}\text { Skillful government } \\
\text { officials (planners, tax } \\
\text { analysts, and property } \\
\text { appraisers) }\end{array}$ & $\begin{array}{l}\text { 1. Build the capacity of } \\
\text { government officials on } \\
\text { skills related to LVC } \\
\text { implementation } \\
\text { 2. Update cadastral data } \\
\text { 3. Establish regulation that } \\
\text { consists of area } \\
\text { development, detailed } \\
\text { procedures, and sanction. } \\
\text { 4. Analyse costs, benefits, } \\
\text { and risks of LVC projects }\end{array}$ \\
\hline $\begin{array}{l}\text { The clear } \\
\text { mechanism of the } \\
\text { jurisdiction (e.g., } \\
\text { implementation of } \\
\text { standard operating } \\
\text { procedures of } \\
\text { permits) }\end{array}$ & $\begin{array}{l}\text { Risk of corruption, } \\
\text { collusion, nepotism }\end{array}$ & $\begin{array}{l}\text { Face-to-face } \\
\text { interaction }\end{array}$ & Increase public trust & $\begin{array}{l}\text { 1. Build e-platform as } \\
\text { information, consultation, } \\
\text { and transaction media } \\
\text { 2. Publish information } \\
\text { through e-platform and/or } \\
\text { mass media } \\
\text { 3. Submit progress report } \\
\text { through e-platform }\end{array}$ \\
\hline $\begin{array}{l}\text { Clear division of } \\
\text { authority }\end{array}$ & $\begin{array}{l}\text { Change in agency } \\
\text { authority }\end{array}$ & $\begin{array}{l}\text { Nomenclature } \\
\text { changes }\end{array}$ & $\begin{array}{l}\text { Skillful government } \\
\text { officials }\end{array}$ & $\begin{array}{l}\text { 1. Establish the } \\
\text { implementing agency } \\
\text { 2. Build the capacity of } \\
\text { government officials on } \\
\text { skills related to LVC } \\
\text { implementation }\end{array}$ \\
\hline
\end{tabular}




\begin{tabular}{|c|c|c|c|c|}
\hline $\begin{array}{l}\text { Effective } \\
\text { coordination among } \\
\text { stakeholders }\end{array}$ & $\begin{array}{l}\text { Decrease in public } \\
\text { participation }\end{array}$ & $\begin{array}{l}\text { Weak government } \\
\text { financial ability }\end{array}$ & Stakeholders' support & $\begin{array}{l}\text { 1. Establish a special public } \\
\text { forum for the LVC project } \\
\text { 2. Conduct intensive } \\
\text { dissemination } \\
\text { 3. Conduct intensive public } \\
\text { forum with stakeholders }\end{array}$ \\
\hline $\begin{array}{l}\text { Strong real estate } \\
\text { market }\end{array}$ & $\begin{array}{l}\text { Public complaints due } \\
\text { to property tax } \\
\text { increase }\end{array}$ & NJOP adjustment & Stakeholder's support & $\begin{array}{l}\text { Conduct intensive } \\
\text { dissemination }\end{array}$ \\
\hline
\end{tabular}

Source: Authors' analysis, 2020

Table 1. proposed several actions that the local government should be fulfilled to address the issues. Firstly, the local government needs to establish a strong implementing agency of LVC with a clear division of roles among related agencies and skillful members. The implementing agency may update cadastral data and property value to have a more accurate analysis before analyzing the costs, benefits, and risks of LVC projects. This action may require high technical skills of government officials; therefore, capacity building is also important to achieve the goal. On the other hand, revaluation of the property value will cause changes in property taxes and raise public objections. Therefore, the implementing agency needs to conduct intensive dissemination before executing LVC projects to gain consensus.

Second, the local government needs to enact regulation that consists of establishing area development, detailed procedures, and sanctions. Because property tax falls under the authority of local governments, it will be easier to implement regulations. After stakeholders reach a consensus, the government may enact the regulations, start the LVC project, and develop the facilities. The implementing agency may also need to establish a special public forum in which property owners and other stakeholders convey their concerns, suggestions, and objection regarding the LVC projects.

Third, to increase public trust, the implementing agency can build an electronic platform (e-platform) to deliver more transparent information and effective media consultations between the private sector and public societies with the local government. The e-platform can also function as a media of transaction where developers can buy such property development rights. To monitor the implementation process, representatives of each stakeholder must submit a progress report of implementing the LVC project through the e-platform to overcome frequent changes in the agencies' authority. Using this progress report, if a task changes, the new person responsible for that task can get input on how to carry out the new tasks. Apart from e-platform, it is also important to disseminate information about the progress of the LVC project through the mass media.

\section{Conclusion}

By conducting qualitative research in Palembang, this paper identified a list of enabling factors and barriers that may influence the implementation of LVC in the future. Even though some precondition for LVC implementation already existed, the local government need to improve and strengthen many features to succeed LVC implementation in Palembang. We argued that before LVC implementation, it is essential to establish an implementing agency of LVC that functions to conduct plan, construct, and monitor LVC projects. Furthermore, achieving a public consensus and increasing public trust is also important because the LVC projects involve various stakeholders from different groups.

This paper involved in-depth interviews with several experts who represent different groups with different backgrounds. However, to cross-check the validity and reliability of the information, the researcher only compared it with secondary data to confirm the interview results. Further research is needed to investigate these issues using a mixed-method approach, combining the interview with a quantitative survey. Future research may also include calculating the benefits from LVC projects. Also, the proposed strategies can be developed in more detail by interviewing other related participants from different agencies, such as the transportation agency and land agency. However, this method is rather time-consuming.

\section{Acknowledgments}

We would like to express our gratitude to Professor Toshihiro Kudo of GRIPS, Palembang Municipal government, all participants, and informants involved in this research. 


\section{References}

Abelson, P. (2018). Analysis of Value Capture Instruments. Economic Papers, 37(4), 399-411. https://doi.org/10.1111/1759-3441.12234

Aveline-Dubach, N., \& Blandeau, G. (2019). The Political Economy of Transit Value Capture: The Changing Business Model of the MTRC in Hong Kong. Urban Studies, 56(16), 1-17. https://doi.org/10.1177\%2F0042098018821519

Berawi, M. A., Suwartha, N., Salsabila, F., Gunawan, Miraj, P., \& Woodhead, R. (2019). Land Value Capture Modeling in Commercial and Office Areas Using a Big Data Approach. International Journal of Technology, 10(6), 1150-1156. https://dx.doi.org/10.14716/ijtech.v10i6.3640

Buchanan, J. (1969). Cost and Choice: An Inquiry in Economic Theory. Liberty Fund.

Buchanan, J., \& Tullock, G. (1962). The Calculus of Consent: Logical Foundations of Constitutional Democracy. Liberty Fund.

Budiati, L. (2020). Building the Integrity of Urban Development Planner Through Corruption Risk Management and Assessment: Literature Review. The Journal of Indonesia Sustainable Development Planning, 1(1), 83-104.

Creswell, J. W. (2009). Research Design: Qualitative, Quantitative, and Mixed Methods Approaches (3rd ed.). Sage Publications, Inc.

Creswell, J. W., \& Poth, C. N. (2018). Qualitative Inquiry and Research Design: Choosing Among Five Approaches (4th ed). Sage Publications, Inc.

Eisinger, P. K. (1988). The Rise of the Entrepreneurial State: State and Local Economic Development Policy in The United States. University of Wisconsin Press.

Falcocchio, J. C., Malik, A., \& Kontokosta, C. E. (2018). A Data-driven Methodology for Equitable Value-capture Financing of Public Transit Operations and Maintenance. Transport Policy, 66, 107-115. https://doi.org/10.1016/j.tranpol.2018.02.005

Gielen, D. M., \& Mualam, N. (2019). A Framework for Analyzing the Effectiveness and Efficiency of Land Readjustment Regulations: Comparison of Germany, Spain and Israel. Land Use Policy, 87. https://doi.org/10.1016/j.landusepol.2019.104077

Gunawan, \& Berawi, M. A. (2018). Conceptual Development of Land Value Capture (LVC) Model in Indonesia Infrastructure Project to Increase Project Benefits. Proceedings of the International Conference on Industrial Engineering and Operations Management, 1027.

Higgins, C. D. (2019). A 4D Spatio-temporal Approach to Modelling Land Value Uplift from Rapid Transit in High Density and Topographically-rich Cities. Landscape and Urban Planning, 185, 68-82. https://doi.org/10.1016/j.landurbplan.2018.12.011

Kerth, R., \& Baxandall, P. (2011). Tax-increment Financing: The Need for Increased Transparency and Accountability in Local Economic Development Subsidies. U.S. PIRG Education Fund.

Kim, J. (2016). Handbook on Urban Infrastructure Finance. New Cities Foundation.

Kim, J. (2018). CePACs and Their Value Capture Viability in the U.S. for Infrastructure Funding (Working Paper WP18JK1).

Komite Percepatan Penyediaan Infrastruktur Prioritas [Committee for the Acceleration of Priority Infrastructure Provision]. (n.d.). Proyek Prioritas: KPPIP [Priority Project]: KPPIP.

Li, X., \& Love, P. E. D. (2020). Employing Land Value Capture in Urban Rail Transit Public Private Partnerships: Retrospective Analysis of Delhi's Airport Metro Express. Research in Transportation B B B Management, 32. https://doi.org/10.1016/j.rtbm.2020.100431

Loo, B. P. Y., Bryson, J. R., Song, M., \& Harris, C. (2018). Risking Multi-billion Decisions on Underground Railways: Land Value Capture, Differential Rent and Financialization in London and Hong Kong. Tunnelling and Underground Space Technology, 81. https://doi.org/10.1016/j.tust.2018.07.011 
Luan, X. F., Lin, X. B., McGuinness, E., \& Yang, J. W. (2014). Emerging Public-private Partnerships in China's Rail Mass Transit Case of Shenzhen. Transportation Research Record, 2450, 127-135. https://doi.org/10.3141/2450-16

Mathur, S. (2014). Special Assessment District's Ability to Fund Transit Lessons from Projectlevel Analysis. Transportation Research Record: Journal of the Transportation Research Board, 2417, 103-110. https://doi.org/doi:10.3141/2417-11

Mathur, S. (2015). Sale of Development Rights to Fund Public Transportation Projects: Insights from Rajkot, India. BRTS Project. Habitat International, 50, 234-239. http://dx.doi.org/10.1016/j.habitatint.2015.08.041

Mathur, S. (2017). Using Tax Increment Financing to Fund Public Transportation: Enabling Environment and Equity Impacts. Public Works Management \& Policy, 22(3), 201-225. https://doi.org/doi:10.1177/1087724X16683404

Mathur, S. (2019). An Evaluative Framework for Examining the Use of Land Value Capture to Fund Public Transportation Projects. Land Use Policy, 86, 357-364. https://doi.org/10.1016/j.landusepol.2019.05.021

Mathur, S., \& Smith, A. (2012). A Decision-support Framework for Using Value Capture to Fund Public Transit: Lessons from Project-specific Analyses (Report No. 11-14). Mineta Transportation Institute.

Medda, F. (2012). Land Value Capture Finance for Transport Accessibility: A Review. Journal of Transport Geography, 25, 154-161. http://dx.doi.org/10.1016/j.jtrangeo.2012.07.013

Mittal, J. (2014). Self-financing Land and Urban Development Via Land Readjustment and Value Capture. Habitat International, 44, 314-323. https://doi.org/10.1016/j.habitatint.2014.07.006

Neville, J. T. J. (2016). Modelling a Land Value Capture Application in Chrischurch, New Zealand. University of Canterbury, Canterbury, New Zealand.

Osborne, D. E., \& Gaebler, T. (1992). Reinventing Government: How the Entrepreneurial Spirit is Transforming the Public Sector.

Ostrom, E., \& Ostrom, V. (2004). The Quest for Meaning in Public Choice. The American Journal of Economics and Sociology, 63(1), 105-147.

Patton, M. (2002). Qualitative Research and Evaluation Methods, 3rd edn. Sage.

Permana, C. T., \& Harsanto, B. (2020). Sustainable City Planning Concepts and Practices in Emerging Economies: A Systematic Review. The Journal of Indonesia Sustainable Development Planning, 1(1), 67-82. https://doi.org/10.46456/jisdep.v1i1.32

Peterson, G. E. (2009). Unlocking Land Values to Finance Urban Infrastructure [Adobe Digital Edition Version].

Public Works and Spatial Planning Agency. (2019). Government Agency Work Report of Public Works and Spatial Planning Agency.

Roukoni, A., \& Medda, F. (2012). Evaluation of Value Capture Mechanisms as a Funding Source for Urban Transport: The Case of London's Crossrail. Social and Behavioural Sciences, 48, 2393-2404. https://doi.org/10.1016/j.sbspro.2012.06.1210

Salon, D., \& Shewmake, S. (2011). Opportunities for Value Capture to Fund Public Transport: A Comprehensive Review of the Literature With a Focus on East Asia.

Sharma, R. (2018). Financing Urban Rail Projects through Land Value Capture -The Indian Case. Curtin University, Perth, Australia.

Sharma, R., \& Newman, P. (2018). Does Urban Rail Increase Land Value in Emerging Cities? Value Uplift from Bangalore Metro. Transportation Research Part A, 117, 70-86. https://doi.org/10.1016/j.tra.2018.08.020

Smolka, M. O. (2013). Implementing Value Capture in Latin America: Policies and Tools for Urban Development (Policy Focus Report Code PF035). Lincoln Institute of Land Policy.

Suzuki, H., Murakami, J., Hong, Y. H., \& Tamayose, B. (2015). Financing Transit-oriented Development with Land Values: Adapting Land Value Capture in Developing Countries [Adobe Digital Edition version]. 
The Palembang National Land Agency (Cartographer). (2015). Land Value Zone Map (ZNT) [map]. 1:40,000.

The Palembang National Land Agency (Cartographer). (2017). Land Value Zone Map (ZNT) [map]. 1:10,000.

Tiebout, C. M. (1956). A Pure Theory of Local Expenditures. Journal of Political Economy, 64(5), 416-424.

Weiss, M. (2014). "Government Entrepreneur" is Not an Oxymoron. Harvard Business Review.

White, R., \& Wahba, S. (2019). Addressing Constraints to Private Financing of Urban (Climate) Infrastructure in Developing Countries. International Journal of Urban Sustainable Development. https://doi.org/doi: 10.1080/19463138.2018.1559970

Wisnu, L. (2019). Value Capturing for Regional Road Development: A Responsive Institutional Design Approach for Indonesia. University of Groningen, Groningen, Netherland.

Wu, J., Hu, Y., Tao, L., \& He, Q. (2018). Value Capture in Protected Areas from the Perspective of Common-pool Resource Governance: A Case Study of Jiuzhai Valley National Park, China. Land Use Policy, 79, 452-462. https://doi.org/10.1016/j.landusepol.2018.08.047

Xu, X., Wang, J., Peng, H., \& Wu, R. (2019). Prediction of academic performance associated with internet usage behaviors using machine learning algorithms. Comput. Human Behav., 98.

Yau, Y. (2012). Homeowner Involvement, la, 2018nd Readjustment, and Sustainable Urban Regeneration in Hong Kong. Journal of Urban Technology, 19(1), 3-22. https://doi.org/doi:10.1080/10630732.2012.626705

Yilmaz, A., Cagdas, V., \& Demir, H. (2015). An Evaluation Framework for Land Readjustment Practices. Land Use Policy, 44, 153-168. http://dx.doi.org/10.1016/j.landusepol.2014.12.004

Zhao, Z. J., Das, K. V., \& Larson, K. (2010). Tax Increment Financing as a Value Capture Strategy in Funding Transportation. Transportation Research Record: Journal of the Transportation Research Board, 2187, 1-7. https://doi.org/doi:10.3141/2187-01

Zhao, Z. J., \& Larson, K. (2011). Special Assessments as a Value Capture Strategy for Public Transit Finance. Public Works Management Policy, 20(10), 1-21. https://doi.org/doi:10.1177/1087724X11408923 